\title{
Servant Leadership Behaviour Scale in the Context of University Student Start-Ups
}

\author{
Tony Antonio ${ }^{1}$, Tina Melinda ${ }^{2}$, and Christina ${ }^{3}$ \\ ${ }^{1}$ Information Technology Program, Universitas Ciputra, Surabaya, Indonesia \\ ${ }^{2}$ Magister Management Program, Universitas Ciputra, Surabaya, Indonesia \\ ${ }^{3}$ International Business Management Program, Universitas Ciputra, Surabaya, Indonesia
}

Corresponding Author:

Tina Melinda

tina.melinda@ciputra.ac.id

Received: 30 December 2019

Accepted: 29 January 2020

Published: 6 February 2020

Publishing services provided by

Knowledge E

(c) Tony Antonio et al. This article

is distributed under the terms of

the Creative Commons

Attribution License, which

permits unrestricted use and

redistribution provided that the

original author and source are

credited.

Selection and Peer-review under the responsibility of the 6 th ICOEN 2019 Conference Committee.

\section{S OPEN ACCESS}

\begin{abstract}
Entrepreneurship and leadership are included as important subject among scholars. Great entrepreneurs have to be great leaders, since they need to have a strong vision, motivate and influence others. The purpose of this paper is to verify the validity and reability of servant leadership behaviour scale in the context of student start-ups. The participants of the study consisted of 300 students who have been working for their start up in Ciputra University Surabaya, Indonesia. Confirmatory factor analysis have been performed to verify the undimensionality and validity of the scale. It is found that the scale can be used in the context of students start up, yet one dimension and 17 indicators should be eliminated from the scale.
\end{abstract}

Keywords: servant leadership, student start-ups, servant leadership behaviour scale, entrepreneurship

\section{Introduction}

Entrepreneurship has been known as one of major contributor for the economic development. Entrepreneurship serve an important function in job creation, economic growth, and development of various geographic entities, from villages to regions and event to entire countries [24].

Entrepreneurship and leadership has become one of the major topics of discussion in the literature. This fact is strengthened by the research and stament of [13] that state the development of entrepreneurship as an interdisciplinary field of study parallels the development of leadership studies. In recent years a number of entrepreneurship researchers have begun to draw on leadership studies for inspiration. [24] has also doing research about trends in and contributions to entrepreneurship reseach, and he found that entrepreneur research fascinated numerous scholars during the study period covering 16.5 years. 
It is unfortunate that leadership has been a major topic of research in psychology and management for almost a century, but many of its concepts and debates have not yet been adopted in entrepreneurship and small business management. It has been identified that leadership has been receiving greater attention in the entrepreneurship literature since it has been recognised that entrepreneurs can not successfully develop new ventures without the presence of effective leadership behaviour [4].

Among many leadership enthusiasts, the idea of being a servant leader is very appealing [10]. A research held by [10] showed that interest in servant leadership has been multiplied since the year 2000. The growth of servant leadership research and publication can be seen in Figure 1.

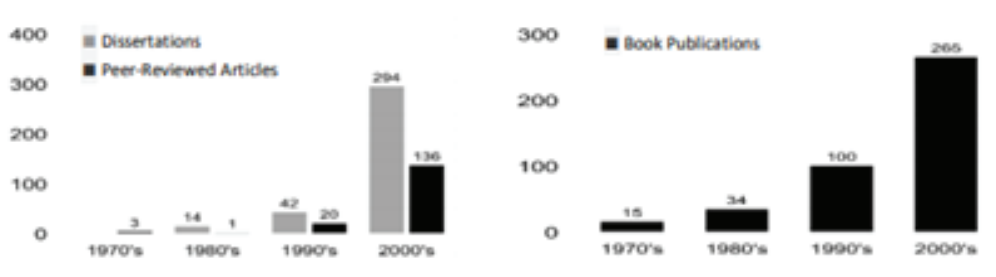

Figure 1: Rise in Publication on Servant Leadership [10].

Previous research showed that servant leadership is a better predictor than transformasional leadership and it is also explains additional variance on team performance, employee satisfaction, commitment and intention to stay, in-role performance, and firm performance. The research before confirmed the reliability and validity of servant leadership to be applied in the corporate context [32].

There are few empirical research that relate entrepreneurship with servant leadership and it is also difficult to find research about servant leadership instrument in higher education. Some of the previous studies correlate servant leadership with social entrepreneurship and social enterprise, such as the research conducted by [26], [27], [20].

[36] proposes servant leadership approach in the academic environment rather than other type of leadership. He writes, "If your goal is to create or enhance a culture that promotes service, individual and collective responsibility, positive and effective relationships, and strong ethics, servant leadership may be the means to your goals". [30] use Servant Leadership Questionnaire (SLQ), constructed by Barbuto and Wheeler to investigate the influence of servant led faculty on student engagement. The study found that the servant leadership model contributes to the deep learning of the student especially the emotional healing attribute. Scardino indicated that servant leadership approach in higher education promotes higher order thinking skills, integrative thinking 
and reflective learning. Higher order thinking is part of higher order learning skill It is a higher level method of thinking than memorizing facts or repeating. This kind of thinking skill is required when learning demands more cognitive processing than others. Integrative thinking covers several behaviors such as emotional healing, wisdom, and persuasive mapping. Reflective learning is the process of reflecting and exploring issue, triggered by an experience which may result and contribute to understanding a situation and a changed conceptual perspective ([7]; [25]).

The purpose of this paper is to verify the validity and reability of servant leadership behaviour scale in the context of students start up. This research is using servant leadership behaviour scale that has been created by Sendjaya since it has been applied in Indonesia before. This research will contribute to the knowledge, especially in the field of entrepreneurship and servant leadership. By knowing the validity and reliability of servant leadership behaviour scale in the context of student start up, it is expected that the instrument can be used to measure the leadership level of the founder and the university can design an appropriate curriculum to develop the servant leadership behaviour of the students.

It is very important to pay attention to the context when we do leadership research since leadership is a process of reality construction that takes place within a specific context [12]. Supporting this statement [23] suggested that leadership success is primarily influenced by the context, which can be described the business environment, company life cycle or the firm structure. Therefore, it is important for scholars consider the context and investigate further the way context influence the variability that may emerge in the constructs under study.

Servant leadership was introduced into an organizational context through Greenleaf's three foundational essays [28]. According to [11], a servant leader is servant first.

"It begins with the natural feeling that one wants to serve. Then conscious choice brings one to aspire to lead. The difference manifests itself in the care taken by the servant---first to make sure that other people's highest priority needs are being served.

Aside referring to Greenleaf, servant leadership researcher also usually cite from Spears and Laub [28]. Larry Spears was the head of Greenleaf Center for nearly two decades. After his long journey in Greenleaf Center and referred to Geenleaf's writing, Spears identified and extracted ten characteristics of servant leaders which are listening, empathy, healing, awareness, persuasion, philosophy, conceptualization, foresight, stewardship, commitment to the growth of people and building the community 
[33]. According to [19], servant leadership is an understanding and practice of leadership that places good of those led over the self-interest of the leader. Laub construct Organizational Leadership Assessment (OLA) instrument, so it can be used to assess or determine the presence of the servant leader characteristics.

[32] has developed a working definition of servant leadership as a holistic approach to leadership that engages both leaders and followes through its (1) service orientation, (2) authenticity focus, (3)relational emphasis, (4) moral courage, (5) spritual motivation, and (6) transforming influence such that they are both transformed into what they are capable of becoming. From the working definition, Sendjaya has four points that he want to be explained. First, servant leadership is a leadership approach that reflects an internal orientation of the heart to serve others. Second, it is a follower centered approach to leadership. Third, it is a holistic approach to leadership and the last point is it has a developmental emphanis, seeking to make positive differences in others.

According to [10] research, there are six instrument for measuring servant leaderhip with a sufficient amount of psychometric development, which are:

1. Organizational Leadership Assessment by Laub [19]

2. Servant Leadership Scale by [10]

3. Servant Leadership Questionnaire by [13]

4. Servant Leadership Scale by [22]

5. Servant Leadership Behaviour Scale by [31]

6. Servant Leadership Survey by [35]

The Organizational Leadership Assessment constructed by Laub consists of six potential sub cores which are, values people, develops people, builds community, display authenticity, provides leadership, shares leadership. The Servant Leadership Scale constructed by Ehrhart consists of four dimensions, which are forming relationships with subordinates, empowering subordinates, helping subordinates grow and succeed, and behaving ethically. The Servant Leadership Questionnaire constructed by Barbuto and Wheeler, measures five aspects of servant leadership, such as altruistic calling, emotional healing, wisdom, persuasive mapping, organizational stewardship. The Servant Leadership Scale constructed by Liden, measures seven dimensions, which are emotional healing, creating value for the community, conceptual skills, empowering, helping subordinates grow and succeed, putting subordinates first, behaving ethically. There are eight dimensions measured by Servant Leadership Survey constructed 
by Dierendonck, which are empowerment, accountability, standing back, humility, authenticity, courage, interpersonal acceptance, stewardship.

[31] examines the development and initial validation of a multidimensional measure of servant leadership behavior. This studies identified more than 20 themes pertinent to servant leadership behavior, then categorized into six different dimension of servant leadership. There are six dimensions in servant leadership behavior scale, which are voluntary subordination, authentic self, covenantal relationship, responsible morality, transcendental spirituality, and transforming influence.

Voluntary subordination is manifested in the willingness to assume the lowliest of positions and endure hardship and suffering on behalf of other people. Two values that are related to this dimension are being a servant and acts of service. Being a servant constitutes the self-concept of the servant leader. The attribute of being a servant mean the way we look at the servant role as being our real responsibility. Our role is to lead, but the real responsibility is to actually make sure that we are serving. Meanwhile through the attribute act of service, the leaders lead other people to be what they are capable of becoming.

Authentic self means knowing and being who they really are. Servant leaders practice what they said, admit their mistakes and limitations and not defensive when their decisions and actions are questioned. Authentic servant leaders manifested in five indicators, which are humility, integrity, accountability, security, and vulnerability.

[32] defined covenantal relationship as behaviors of the leader that foster genuine, profound and lasting relationships with followers. In order to build covenantal relationship, servant leaders need to rely on acceptance, availability, equality, and collaboration.

Servant leadership is diverse from other leadership approaches due to its emphasis on followers' development, mainly in the area of responsible morality [9]. Responsible morality is manifested in the leader's moral reasoning and moral action. Moral reasoning refers to implicit cognitive processing used to justify one's decisions or actions [17]. Moral action is a behavioral manifestation, verbal or non-verbal, that one undertakes on the basis of moral deliberation.

Transcendental spirituality is defined as behaviors of the leaders which manifest an inner conviction that something or someone beyond self and the material world exists and makes life complete and meaningful. There are four values of transcendental spirituality, which are transcendental beliefs, interconnectedness, sense of mission and wholeness.

Transforming influence is the behaviors of the leader that help employees to be what the are capable of becoming. There are five values of servant leaders' transforming 
influence, which are vision, empowerment, modeling, mentoring and trust. Servant leaders transform their followers to be servant leaders by casting vision, empowering, role modeling, mentoring, and trusting them.

The summary of the six dimensions and values of servant leadership behavior scale can be seen in Table 1.

TABLE 1: Dimensions and Values of Servant Leadership.

\begin{tabular}{|c|c|}
\hline Dimension & Definition \\
\hline Voluntary Subordination & $\begin{array}{l}\text { A willingness to take up opportunities to } \\
\text { serve others whenever there is a } \\
\text { legitimate need, regardless of the nature } \\
\text { of the service, the person served or the } \\
\text { mood of the servant leader }\end{array}$ \\
\hline Authentic Self & $\begin{array}{l}\text { A consistent display of humility, integrity, } \\
\text { accountability, security and vulnerability } \\
\text { A willingness to work quietly behind the } \\
\text { scenes, spend time on small things and } \\
\text { make seemingly inconseguential } \\
\text { decisions in an unrewarded an unnoticed } \\
\text { fashion }\end{array}$ \\
\hline Covenantal Relationship & $\begin{array}{l}\text { Engaging with and accepting others for } \\
\text { who they are, not for how they make } \\
\text { servant leaders feel }\end{array}$ \\
\hline Responsible Morality & $\begin{array}{l}\text { Ensuring that both the ends they seek } \\
\text { and the means they employ are morally } \\
\text { legitimized thoughtfully reasoned and } \\
\text { ethically justified }\end{array}$ \\
\hline Transcendental Spirituality & $\begin{array}{l}\text { Attuned to the idea of calling in seeking } \\
\text { to make a difference in the lives of others } \\
\text { through service, from which one derives } \\
\text { the meaning and purpose of life }\end{array}$ \\
\hline Transforming influence & $\begin{array}{l}\text { Positively transforming others in multiple } \\
\text { dimensions (e.g. emotionally, intellectualy, } \\
\text { socially and spritually) into servant leaders } \\
\text { themselves }\end{array}$ \\
\hline
\end{tabular}

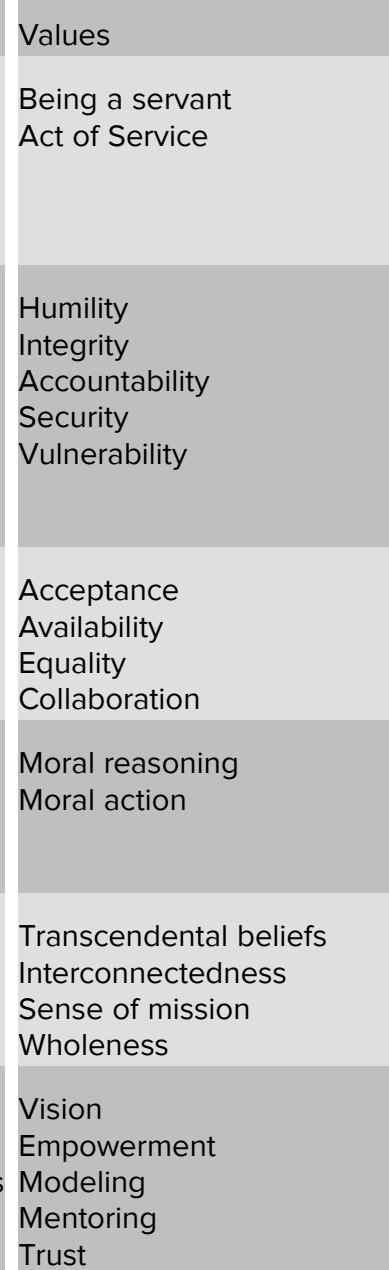

Source: [32] and [10]

Startup has different characteristic with other kind of firm. [18] identifies four possible forms of new firm formation, using the dimensions of resource sharing and parental support. This possible forms of new forms of new formation can be seen in Figure 2.

As can be seen in Figure 2, individual startups are based on resources that mainly originate from the entrepreneur, there are no resource sharing and parental support. Similar thought has been stated before by [34] which stated that startups operate in a unique context which is characterized by the tendency of newness, smallness and uncertainty [37]. Entrepreneurship is compulsory subject for all students in Universitas 


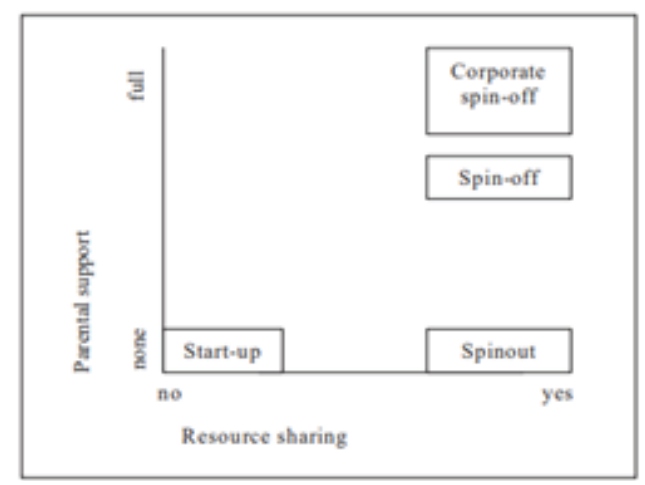

Figure 2: Firm Founding Type [18].

Ciputra for five semester. Each class consists of 40 to 50 students from different majors in order to achieve an interdisciplinary learning environment [2]. Each of the entrepreneurship subject has different emphasis. Entrepreneurship 1 emphasize on building entrepreneurship mindset on the students. Students are encourage to help or give impact to communities. Students are encourage to collaborate each other and think about how to help this communities. In Entrepreneurship 2, students learn about how to generate ideas and how to create business model. Usually students do the entrepreneurship project in a group. The maximum member of a group are five students. Entrepreneurship 3 focus on the execution of the idea and the business model that has been established in the $2^{\text {nd }}$ semester. Entrepreneurship 4 stress on the innovation learning. Students learn to analyze the internal and external factor that can influence their business and make an innovation plan to make their business grow. In the fifth semester, students will take entrepreneurship 5 and encouraged to participate in foreign trade fair and try to introduce their product to the international market.

It is found that the SLBS is verified and validated properly which means that the scale is suitable for student and student start up purpose.

\section{Method}

The servant leadership behaviour scale questionnaire is given to the fourth semester of Ciputra University students. Ciputra University students are different with other university students, since they experiencing the entrepreneurship subject for five semesters and forced to execute their business idea since the third semester. In general, other university students only learn entrepreneurship for one until two semesters. There are 210 start-up projects in the fourth semester. The main reason of the sample selection are because Universitas Ciputra focus on entrepreneurship education, the students learn 
entrepreneurship intensively and have executed their business project for six until 12 months. The criterias for the participants are student who are still running their business project, consist of three until five members in a group and participate as a member of the group and not the CEO.

Questionnaires were administered to 300 participants. However in completing the questionnaires, only 219 out of 300 participants completed them. Out of 219 questionnaires, some found inconsistent in completing the questionnaires and some need to be deleted to eliminate the outlier and get better result of analysis. So, at the end only 199 questionnaires used in the final analysis. The participants are students from different majors such as international business management, information and multimedia technology, business information system, psychology, accounting, culinary business, hospitality, fashion, visual communication design and interior architecture. Business projects executed by the students are generally engaged in the field of trading, service, food and beverage, design, fashion, and technology.

Confirmatory factor analysis have been performed by using SmartPLS to verify undimensionality, convergent validity, and concurrent validity of servant leadership behaviour scale. Although PLS is well known for handling small sample sizes, there was previous research that suggests a sample size of 100 to 200 as a good starting point in carrying out path modeling [14].

\section{Result}

According to [15], indicator's outer loading should exceed 0.7. Based on the indicator's outer loading result, there are 11 indicators which do not comply the treshold and should be deleted. The analysis result that shown in Table 2 until Table 4 is a result after the 11 indicators deleted.

Two criterias for testing goodnes of measure are validity and reliability. The validity and reliability is showed by the Average Variance Extracted (AVE), composite reliability, and cronbachs alpha. The result of the validity and reliability of this studies can be seen in Table 2.

[16] stated that composite reliability could be more appropriate than cronbach's alpha. Composite reliability should be higher than 0.7 [5], and AVE value $>0.5$ indicates sufficient convergent validity.

Table 2. shows that the construct indicators indicate the latent since the construct ranged from 0.84 to 1 and surpass the recommended value of 0.7. The result of AVE 
TABLE 2: Average Variance Extracted (AVE), Composite Reliability, R square, Cronbach Alpha.

\begin{tabular}{|l|c|c|c|c|}
\hline & AVE & $\begin{array}{c}\text { Composite } \\
\text { Reliability }\end{array}$ & R Square & $\begin{array}{c}\text { Cronbachs } \\
\text { Alpha }\end{array}$ \\
\hline Servant Leadership & 0.500194 & 0.954515 & & 0.949903 \\
\hline Voluntary Subordination & 0.576815 & 0.871891 & 0.848672 & 0.816118 \\
\hline Authentic Self & 0.726385 & 0.841484 & 0.664188 & 0.623771 \\
\hline Covental Relationship & 1.000 .000 & $1.000,000$ & 0.515445 & $1.000,000$ \\
\hline Responsible Morality & 0.604651 & 0.859408 & 0.830074 & 0.781880 \\
\hline Trancendental Spirituality & 0.724672 & 0.840358 & 0.692755 & 0.620075 \\
\hline Transforming Influence & 0.561314 & 0.899455 & 0.908970 & 0.869424 \\
\hline
\end{tabular}

are greater than the suggested value, which is 0.5 , indicate that each construct has sufficient convergent validity.

Discriminant validity show the degree to which items differentiate among constructs. It was assessed by verifying the corelations between the measures of potentially overlapping constructs. Items should load more strongly on their own construct, and the average variance between the construct and its indicators should be larger than the construct and other construct. [3]. Table 3. display the Result of the discriminant validity of the measures.

TABLE 3: The Discriminant Validity of The Measures.

\begin{tabular}{|c|c|c|c|c|c|c|}
\hline & $\begin{array}{c}\text { Servant } \\
\text { Leadership }\end{array}$ & VS & AS & CR & TS & TI \\
\hline $\begin{array}{l}\text { Voluntary Subordination } \\
\text { (VS) }\end{array}$ & 0.921234 & 1.000 .000 & & & & \\
\hline Authentic Self (AS) & 0.814977 & 0.758188 & 1.000 .000 & & & \\
\hline Covental Relationship(CR) & 0.717945 & 0.646611 & 0.566548 & 1.000 .000 & & \\
\hline Responsible Morality (RM) & 0.911084 & 0.791772 & 0.688211 & 0.638100 & 1.000 .000 & \\
\hline $\begin{array}{l}\text { Trancendental Spirituality } \\
\text { (TS) }\end{array}$ & 0.832319 & 0.692020 & 0.619273 & 0.553959 & 0.716776 & 1.000 .000 \\
\hline Transforming Influence (TI) & 0.953399 & 0.823594 & 0.715564 & 0.623231 & 0.836827 & 0.796950 \\
\hline
\end{tabular}

As seen in Table 3. all of the constructs share more variance with their indicators than with other constructs. The diagonal valus in bold are higher than off-diagonal ones. This shows the existance of discriminate validity.

Confirmatory Factor Analysis is used to assess item loading and cross loadings. Table 4 show the cross loading result. The result shows that all of the items have high loading on their respective constuct. 
TABLE 4: Cross loading Result.

\begin{tabular}{|c|c|c|c|c|c|c|c|}
\hline & VS & AS & CR & RM & TS & TI & $\begin{array}{c}\text { Servant } \\
\text { Leadership }\end{array}$ \\
\hline X7 & 0.761627 & 0.537290 & 0.463741 & 0.582374 & 0.514064 & 0.639426 & 0.692897 \\
\hline X13 & 0.769955 & 0.670554 & 0.491200 & 0.693031 & 0.565669 & 0.651704 & 0.746440 \\
\hline$\times 25$ & 0.704878 & 0.464637 & 0.429922 & 0.584853 & 0.445069 & 0.636114 & 0.658248 \\
\hline X30 & 0.785361 & 0.575541 & 0.534373 & 0.599202 & 0.549564 & 0.593524 & 0.700971 \\
\hline X34 & 0.772997 & 0.619087 & 0.533335 & 0.540569 & 0.546938 & 0.606766 & 0.695255 \\
\hline$x 8$ & 0.667635 & 0.840226 & 0.403644 & 0.545027 & 0.462791 & 0.587152 & 0.668007 \\
\hline X14 & 0.626820 & 0.864171 & 0.556767 & 0.625566 & 0.588554 & 0.631439 & 0.719831 \\
\hline$x 5$ & 0.561007 & 0.452819 & 0.475245 & 0.753234 & 0.501422 & 0.623784 & 0.662220 \\
\hline X11 & 0.582609 & 0.566573 & 0.459200 & 0.794110 & 0.531332 & 0.629552 & 0.694247 \\
\hline X23 & 0.657744 & 0.546107 & 0.504839 & 0.803713 & 0.612456 & 0.701914 & 0.750566 \\
\hline X28 & 0.654826 & 0.569873 & 0.542712 & 0.758074 & 0.577268 & 0.643510 & 0.721815 \\
\hline X10 & 0.588240 & 0.523842 & 0.527636 & 0.611028 & 0.849396 & 0.655627 & 0.704401 \\
\hline X22 & 0.589963 & 0.530477 & 0.416166 & 0.609343 & 0.853153 & 0.700972 & 0.712633 \\
\hline X6 & 0.654621 & 0.579173 & 0.468724 & 0.632683 & 0.647488 & 0.754552 & 0.737942 \\
\hline X12 & 0.608074 & 0.556467 & 0.422993 & 0.637197 & 0.578654 & 0.752727 & 0.712165 \\
\hline X18 & 0.611362 & 0.510114 & 0.413778 & 0.591279 & 0.666139 & 0.769017 & 0.713391 \\
\hline X24 & 0.622324 & 0.519557 & 0.456991 & 0.629435 & 0.526445 & 0.717494 & 0.693704 \\
\hline X29 & 0.683229 & 0.538279 & 0.524522 & 0.674890 & 0.608325 & 0.794540 & 0.762413 \\
\hline X33 & 0.536116 & 0.522208 & 0.447413 & 0.654385 & 0.505183 & 0.737893 & 0.681914 \\
\hline X35 & 0.595692 & 0.525717 & 0.532109 & 0.567030 & 0.641911 & 0.715042 & 0.694153 \\
\hline
\end{tabular}

\section{Discussion}

From the validity and reliability result, and also the cross loading result, indicates that the servant leadership behavioral scale can be used in the context of student start up, but not all of the indicators can be used. From the analysis, one dimension and 17 items of indicators were eliminated. There are some factors that may be the reason of the elimination such as the difference between a start up and corporate context, and also the difference characteristic of the respondents. In young enterprises context, the leadership is simpler rather than leadership in established firm [1]. Startups tend to have limited resource. This condition often lead to a flat organization with a small number of hierarchy levels, only one management level exist which is led by the founder-CEO. [37]. Usually the respondents for servant leadership measurement are professionals who are already graduate from universities, mature in characteristic and already have 
experiences working with other people. On this research, the respondents are students member who assess their CEO or leader whom also a student and lack of experience. The age and experiences difference between professionals and students can be the reason why do some indicators should be deleted from the instruments. Yet there are still five dimensions used to measure servant leadership.

The dimension that eliminated was covenantal relationship. The outer loading of all covenantal relationship were below 0.7 and all indicators should be eliminated. Covenantal relationship was defined as behaviors of the leader that foster genuine, profound and lasting relationship with followers. In order to build covenantal relationship, servant leaders should build acceptance, availability, equality and collaboration [32]. Reason that may cause this dimension was not valid and reliable to measure servant leader in students context was the short life of the startup project being run. Mostly they have run the project in short period which was six until 12 months.

Two indicators were eliminated from voluntary subordination, one indicator was from the value of being a servant, this causes no indicator representing the values of being a servant. The other indicator was from the value act of service, which is serve others with no regards of backgrounds (gender, race, etc).

Four indicators were eliminated from authentic self, one indicator was from the value of humility, two indicators from the values of vulnerability, and one indicator from the value of security. This means that no indicator left to measure humility, vulnerability and security. The values that are left for the authentic self dimension are integrity and accountability.

One indicator was eliminated from the responsible morality, which was from the value of moral action. There were three indicators left for the value of moral action, after the indicator employ morally justified means to achieve legitimate ends eliminated.

Two indicators were eliminated from transcendental spirituality, one indicator was from the value of transcendental belief, and the other was from the value of wholeness. This causes no indicator left for the value of transcendental belief and wholeness. The values that are left for transcendental spirituality dimension are interconnectedness and sense of mission.

Two indicators were eliminated from transforming influence, one indicator was from the value of vision and the other was from the value of mentoring. It means that no indicator left for the value of vision and mentoring. The values for transforming influence dimension are empowerment, modeling and trust. This makes sense since generally students have no or little industry experience. 
The study shows that leadership behavior especially servant leadership behavior is significant to the student start up and is suitable to measure the dimension of the behavior for university start up.

This research provides evidence about validity and reliability of the servant leadership behavioral scale in the context of students start up. It successfully confirmed that the scale can be used in the context of student start up but not all dimensions and indicators are valid and reliable to measure servant leaders.

The servant leadership instrument used in this study is servant leadership behavior scale by Sendjaya, since it conceives transformational and transcendental spirituality which make this instrument different from the other scale or instruments. The servant leadership behavior scale was designed for corporate context, it will be better for the next research to modify and simplify the sentences in the questionnaire, adjust to the students context. Further research need to be conducted in order to investigate the influence of servant leader on startup performance.

Furthermore, universities and academic leaders can utilize this scale and design appropriate curriculum to develop the servant leadership behaviour of the students.

\section{Funding}

The work was supported by the Directorate of Research and Community Services,

Directorate General of Strengthening for Research and Development Ministry of Research Technology and Higher Education, Republic of Indonesia

\section{Acknowledgement}

The authors would like to thank Directorate of Research and Community Services,

Directorate General of Strengthening for Research and Development Ministry of Research Technology and Higher Education, Republic of Indonesia, and also thankfull to Department of Research and Publication Ciputra University

\section{Conflict of Interest}

In doing this research, there was no personal relations with other people or organizations that could inapproprietely influence the work. 


\section{References}

[1] Aldrich, H., \& Auster, E. R. (1986). Even Dwarfs Started Small: Liabilities of Age and Size and Their Strategic Implications. Research in Organizational Behavior, 8, 165198.

[2] Antonio, T. (2012). Inspiring Wednesday, Ciputra University Best Practice in Shaping Entrepreneurs in Higher Education. Jurnal Entrepreneur dan Entrepreneurship, 1(1), 21-27.

[3] Agarwal, R., and Karahanna, E. (2000). Time flies when you're having fun: Cognitive absorption and beliefs about information technology usage. MIS Quarterly,24 (4), 665-694.

[4] Arham, A.F., Boucher, C., Muenjohn, N. (2013). Leadership and Entrepreneurial Success: A Study of SMEs in Malaysia. World of Journal Social Sciences, 3(5), 117-130.

[5] Bagozzi, R. and Yi, Y. (1988) On the Evaluation of Structural Equation Models. Journal of the Academy of Marketing Sciences, 16, 74-94.

[6] Barbuto, J.E, Jr, Wheeler, D.W. (2006). Scale Development and Construct Clarification of Servant Leadership. Group \& Organization Management, 31:300--326.

[7] Boyd, E., \& Fales, A. (1983). Reflective learning: Key to learning from experience. Journal of Humanistic Psychology, 23, 99-117.

[8] Ehrhart, M.G. (2004). Leadership and Procedural Justice Climate as Antecedents of Unit-Level Organizational Citizenship Behavior. Personnel Psychology, 57:61--95.

[9] Graham, J. (1991). Servant-Leadership in Organizations: Inspirational and Moral. Leadership Quaterly, 2(2), 105-119.

[10] Green, M.T., Rodiguesz, R.A., Wheeler, C.A., Hinojosa, B.B. (2015). Servant Leadership: A Quantitative Review of Instruments and Related Findings. Servant Leadership: Theory and Practice, 2(2), 76-96.

[11] Greenleaf, R.K. (1977). Servant Leadership: Journey into the Nature of Legitimate Power and Greatness. New York: Paulist Press.

[12] Hamilton, F \& Bean, C.J. (2005). The Importance of Context, Beliefs and Values in Leadership Development. Business Ethics, 14 (4), 336-347.

[13] Harrison, R.T., Leitch, C.M. (2006). Entrepreneurship and Leadership: The Implication for Education and Development. Journal of Entrepreneurship \& Regional Development, 6(2), 111-125.

[14] Hoyle, R. H. (1995). Structural Equation Modeling. Thousand Oaks, CA.: Sage Publications. 
[15] Hair, J. F., Hult, G. T. M., Ringle, C., \& Sarstedt, M. (2014). A Primer on Partial Least Squares Structural Equation Modeling (PLS-SEM). Sage Publications, Inc.

[16] Henseler, J, Ringle, CM \& Sinkovics, R.R. (2009). The use of partial least squares path modeling in international marketing. in Advances in International Marketing. Advances in International Marketing, 20 (1), 277-319.

[17] Kohlberg, L. (1984). The psychology of moral development: The nature and validity of moral stages. San Francisco: Harper \& Row.

[18] Koster, S. (2004). Spin-off firm and Individual Start-ups. Are They Really Different? Ersa Conference Paper, Porto.

[19] Laub, J. (1999). Assessing the servant organization: Development of the servant organizational leadership (SOLA) instrument. Dissertation Abstracts International, 60(02), 308.

[20] Latiff, A, Majid, I.A., Mohamad, M. (2017). Exploring Servant Leadership Instrument for Social Enterprise (Cooperative). European Journal of Multidisciplinary Studies, 4 (3), 7-23.

[21] Leitch, C.M., Volery, T. (2017). Entrepreneurial Leadership: Insight and Directions. International Small Business Journal: Researching Entrepreneurship, 35(2):147-156.

[22] Liden, R. C., Wayne, S. J., Zhao, H., \& Henderson, D. (2008). Servant Leadership: Development of a Multidimensional Measure and Multi-Level Assessment. The Leadership Quarterly, 19, 161--177.

[23] Liden, R. C., \& Antonakis, J. (2009). Considering context in psychological leadership research. Human Relations, 62(11), 1587--1605.

[24] Luor, T., Lu H.P., Yu, H., Chang, K. (2014). Trends in and Contributions to Entrepreneurship Research: A Broad Review of Literature from 1996 to June 2012. Scienctometrics, 99 (2), 353-369.

[25] Mckenna, A.F., Yalvac, B., \& Light, G.J. (2009). The Role of Collaborative Reflection on Shaping Engineering Faculty Teaching Approaches. Journal of Engineering Education, 98, 17-26.

[26] Mohamad, M, and Majid, I.A. (2014). Entrepreneurial Servant Leadership (ESL): A Proposed Leadership Model for Social Enterprise (Cooperative). International Journal of Technical Research and Application, 2(8), 51-57.

[27] Petrovskaya, I, Mirakyan, A. (2016). A Mission of Service: Social Entrepreneur as A Servant Leader. International Journal of Entrepreneurial Behavior \& Research.

[28] Parris, D. L., \& Peachey, J. W. (2013). A Systematic Literature Review of Servant Leadership Theory in Organizational Contexts. Journal of Business Ethics, 113(3), 377--393. 
[29] Russel, R.F., Stone, A.G. (2002). A Review of Servant Leadership Attributes: Developing a Practical Model. Leadership \& Organization Development Journal., 145-157.

[30] Scardino, A.J. (2013). Servant Leadership in Higher Education: The Influence of Servant-Led Faculty on Student Engagement. Doctoral Dissertation, Antioch University.

[31] Sendjaya, S., Sarros, J.C., Santora, J.C., (2008). Defining and Measuring Servant Leadership Behaviour in Organizations. Journal of Management Studies, 45, 402424.

[32] Sendjaya, S. (2015) Personal and Organizational Excellence Through Servant Leadership: Learning to Serve, Serving to Lead, Leading to Transform. Switzerland: Springer International Publishing Switzerland

[33] Spears, L. C. (2010). Character and Servant Leadership: Ten Characteristics of Effective, Caring Leaders. The Journal of Virtues \& Leadership, 1(1), 25--30.

[34] Stinchcombe, A. (1965). Social Structure and Organizations. In J. March (Ed.), Handbook of organizations (pp. 142--193). Woods Drive Skokie: Rand McNally.

[35] Van Dierendonck, D., \& Nuijten, I. (2011). The Servant Leadership Survey: Development and Validation of a Multidimensional Measure. Journal of Business \& Psychology, 26, 249-267.

[36] Wheeler, D.W. (2012). Servant Leadership for Higher Education. United State of America: John Wiley \& Sons, Inc.

[37] Zach, S \& Baldegger, U. (2017). Leadership in Start-ups. International Small Business Journal: Researching Entrepreneurship, 35 (2). 